\title{
Disrupting Anti-Blackness with Young Learners in STEM: Strategies for Elementary Science and Mathematics Teacher Education
}

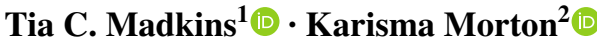

Accepted: 11 June 2021 / Published online: 5 August 2021

(C) Ontario Institute for Studies in Education (OISE) 2021

\begin{abstract}
If we envision a future for Black young learners where their full humanity is honoured and educators facilitate rigorous science, technology, engineering, and mathematics (STEM) learning experiences that are justice-focused, we must disrupt systemic racism now. In this article we discuss how anti-Blackness is pervasive in science and mathematics education, especially for young learners. We also address why teacher educators must disrupt anti-Black racism in our work with elementary teacher candidates and in our research. We argue that to do this work and disrupt anti-Blackness, elementary teacher educators and teacher candidates need political clarity (Beauboeuf-LaFontant, 1999). Political clarity is the understanding of how structural and school inequalities work to (re)produce differential learning experiences for minoritized learners. We offer suggestions for how teacher educators can further develop their teacher candidates' political clarity. Drawing upon our prior research, course assignments, and experiences as Black women educators and teacher educators, we share examples of how an individual's political clarity can be developed within science and mathematics methods courses. In doing so, we build upon prior research in STEM teacher education on how teachers come to see teaching as a political act and engage in the hard work of equity-focused STEM teaching.
\end{abstract}

Résumé Pour envisager un avenir propice à respecter l'humanité à part entière des jeunes apprenants noirs et où les éducateurs mettent en valeur des expériences d'apprentissage rigoureuses et axées sur la justice en sciences, technologie, ingénierie et mathématiques (STIM), nous devons dès maintenant briser le cycle du racisme systémique. C'est pourquoi nous traitons de l'omniprésence d'une logique anti-noire dans l'enseignement des sciences et des mathématiques, qui touche particulièrement les jeunes apprenants. Dans notre travail avec les candidats à l'enseignement au primaire et notre recherche, nous tentons aussi de déterminer pourquoi les formateurs d'enseignants doivent s'attaquer au racisme anti-noir. Nous soutenons que pour accomplir ce travail et contrer la logique anti-noire, les formateurs d'enseignants destinés au primaire et les candidats à l'enseignement ont besoin de clarté

Tia C. Madkins

tmadkins@austin.utexas.edu

1 College of Education, The University of Texas at Austin, 1912 Speedway, Stop D5500, Austin, TX 78712, USA

2 College of Education, The University of North Texas, 1155 Union Circle, Denton, TX 76203, USA 
politique (Beauboeuf-LaFontant, 1999). La clarté politique est définie comme étant la compréhension de la façon dont les inégalités structurelles et scolaires fonctionnent pour (re) produire des écarts en ce qui concerne les expériences d'apprentissage des apprenants issus de minorités. Nous offrons des suggestions quant aux moyens que peuvent prendre les formateurs d'enseignants pour développer davantage la clarté politique de leurs candidats à l'enseignement. Puisant à même nos recherches antérieures, des travaux réalisés dans le cadre de cours et nos expériences en tant que femmes noires éducatrices et formatrices d'enseignants, nous partageons des exemples qui démontrent que la clarté politique d'un individu peut être développée dans les cours de sciences et de méthodes mathématiques. Ce faisant, nous nous appuyons sur des recherches antérieures dans le domaine de la formation des enseignants en STIM sur la façon dont les enseignants en viennent à considérer l'enseignement comme un acte politique et à s'engager dans le travail inlassable d'un enseignement des STIM fondé sur l'équité.

Keywords Anti-Blackness $\cdot$ Anti-racist teaching $\cdot$ Equity $\cdot$ Political clarity $\cdot$ Elementary STEM education

As our global public health, education, and race crises continue to converge, inequalities in our educational systems have become even more apparent. During our global \#FedUpRising, we have witnessed inequitable access to remote schooling, healthcare, and more in North America (i.e. land nations we commonly refer to as Canada and the USA). Unsurprisingly, Black people and other racially minoritized communities have been disproportionately affected by the health, educational, and economic effects of the pandemic (CDC, 2020; Bennett, 2020; Hou et al., 2020; Katayama et al., 2020). For some time prior to the COVID-19 era, science, technology, engineering, and mathematics (STEM) education scholars have called out and addressed the pervasiveness of these inequalities. These critical STEM education scholars who pursue justice-oriented research agendas discuss anti-Blackness across schooling contexts, especially for young learners (e.g. R. Gutiérrez et al., 2018; Madkins \& McKinney de Royston, 2019; Martin, 2003; Mensah, 2013; Nxumalo, 2019; Secada, 1989). Our current sociopolitical climate has increased attention to these issues in both scholarly and popular press publications (e.g. Bang, 2020; Block, 2020; Madkins et al., 2020; Morales-Doyle et al., 2020). Scholar activists, researchers, and practitioners alike have made these instantiations of systemic racism more visible, sparking activism and resistance via social media and other outlets (e.g. \#ShutDownSTEM, \#ShutDownAcademia, \#ScholarStrike).

The ways structural racism and racist schooling practices influence Black learners' opportunities to learn are well documented in educational research (Carter \& Reardon, 2014; Tuck \& Yang, 2018). In STEM education specifically, this can begin as early as elementary school. For example, racialized disparities in access to high-quality mathematics and science instruction and educational outcomes, such as achievement or interest, can start as early as first grade in the USA (Banks et al., 2007; NAEP, 2015, 2016). Disparate outcomes can have long-lasting effects on young learners' academic trajectories when they pursue advanced STEM courses in secondary and post-secondary settings (Irizarry, 2021; Morton \& Riegle-Crumb, 2019, 2020; NRC, 2012). More importantly, anti-Black racism affects young learners' access to equitable and rigorous STEM learning opportunities. Thus, disrupting anti-Blackness early in schooling is critical for young learners to have equitable, just, and sustainable learning experiences. In so doing, young learners would be supported in simultaneous development of conceptual understandings, identity development, and other educational outcomes in science and mathematics.

In this article, we focus on what elementary mathematics and science teacher educators can do to disrupt anti-Blackness in STEM education. Though teacher educators (TEs) may desire to disrupt antiBlackness and support their teacher candidates (TCs) to do the same, some TCs are resistant to committing to anti-racist dispositions and teaching practices. This is especially true for those TCs working 
with young learners (Freire \& Valdez, 2017; Sleeter, 2012; Young, 2010). This is unsurprising since researchers have shown that race, racism, and systemic inequities are difficult concepts for TCs to grapple with over time (Guinier, 2004; Larkin et al., 2016; Leonardo, 2009; Philip, 2011). Nonetheless, given our current sociopolitical climate and the dearth of literature specific to anti-Blackness in K-5 science and mathematics classrooms, we see this work as relevant, necessary, and urgent. If we envision a future for young learners who identify as Black where their full humanity is honoured and educators facilitate rigorous STEM learning experiences that are justice-focused, we must disrupt systemic racism now.

Therefore, we address how anti-Blackness is pervasive in science and mathematics education, especially for young learners. Though all minoritized learners are affected by the myriad ways white supremacy influences how schools and classrooms are organized and function, here, we specifically focus on anti-Black racism. We argue that one of the many roles of TEs is to disrupt these systems of power in our work with TCs and in our research. To do this work, TEs and TCs need political clarity (Bartolomé, 1994; Beauboeuf-LaFontant, 1999), which is the understanding of the sociopolitical and classed realities that shape our learners' lived experiences, and how structural and school inequalities work to (re)produce differential learning experiences for minoritized learners. We offer suggestions of how TEs can support their TCs in developing political clarity. In so doing, we build upon prior research in STEM teacher education on how teachers come to see teaching as a political act and engage in the difficult and risky work of anti-racist STEM teaching (e.g. Calabrese Barton \& Tan, 2020; Madkins \& McKinney de Royston, 2019; Philip, 2011).

We begin by sharing our researcher positionality statements and outlining our research and teaching commitments in order to help our audience understand how our experiences shape our approach to our work and clarify the asset-based terms we use in this article. We then offer a brief synthesis of the literature related to anti-Black racism and the nuanced ways this form of racism operates within science and mathematics education. Next, we discuss political clarity (Bartolomé, 1994; Beauboeuf-LaFontant, 1999) and why it is necessary for disrupting anti-Blackness within teacher education, schools, and classrooms. Finally, drawing upon our prior research and our experiences as Black women teachers and teacher educators, we share examples of how TEs can engage in this work in the context of their elementary science and mathematics methods courses. For example, we share features of course activities and assignments we use in mathematics and science methods courses at our universities to support TCs' political clarity development. These examples represent how we see our work contributing to the ways we can disrupt anti-Blackness in elementary STEM education.

\section{Researcher Positionality Statements}

Below, we share our researcher positionality statements, which allow researchers to deeply examine "the practice of their inquiry" (Milner, 2007, pp. 394-395), particularly in teacher education. In so doing, we hope to make visible the experiences we bring to our research and teaching that shape our anti-racist approaches (Jafar, 2018; Milner, 2007).

Madkins I am a cis-gender and heterosexual Black woman researcher and teacher educator who grew up in the Southeastern USA, where both my maternal and paternal ancestors were enslaved. Across my K-12 schooling experiences, I enjoyed learning science-especially biology and chemistry. I was often the only or one of the few Black learners in my honours and Advanced Placement science courses during my high school career. My family members, teachers, and friends encouraged me to pursue my interests in postsecondary STEM. After graduating from college with a biology degree and a pre-med emphasis, I chose to pursue a master's degree in science education and earn an elementary teaching credential at the University of Southern California instead of a career in medicine. Though this was initially disappointing to my parents, they saw how fulfilled I was working with young children in my 
elementary classroom in the Los Angeles area. Similar to other Black womxn educators who are from the Deep South, I have countless family members who are/were educators and have worked with multiple generations of minoritized learners in public schools (Dixson \& Dingus, 2008). As such, I found so much joy in knowing I was also a part of this historical tradition (Givens, 2021a, b; Madkins, 2011; McKinney de Royston et al., 2021) and in the daily intellectual and socioemotional work of teaching. My professional experiences as a PK-8 teacher in Los Angeles and the San Francisco Bay Area, as well as my research experiences in both in and out-of-school STEM classrooms, have informed my justiceoriented approaches and research agenda. I understand how deficit narratives rooted in racist ideologies operate in nuanced ways—-both explicitly and implicitly — within schooling contexts based on this intergenerational, experiential knowledge (Carter \& Reardon, 2014; Kendi, 2017; Davis \& Museus, 2019; Tuck \& Yang, 2018). These narratives are especially prevalent in elementary science and mathematics classrooms (Martin, 2013; Nasir \& Bang, 2012; Sheth, 2019) in my experiences as an educator and learner. My work as a researcher and teacher educator in STEM education is shaped by these professional and educational experiences. Therefore, I decentre whiteness in my STEM education research and elementary science methods courses by prioritizing asset-based perspectives and scholarship. In so doing, I aim to foster and maintain humanizing classrooms (del Carmen Salazar, 2013) and research (Souto-Manning \& Winn, 2019) to better prepare teacher candidates to disrupt anti-Blackness in their future work with young learners as science teachers (Table 1).

Morton I am a Black woman from the US Virgin Islands, a territory of the USA composed of a predominantly Black population. Fortunately, my schooling experiences as a child were largely positive and empowering, likely heavily influenced by the protective and nurturing acts of the Black men and women I had the privilege of having as teachers (McKinney de Royston et al., 2021). As a young Black girl, I was often encouraged by my teachers to excel academically and to pursue STEM, and as such, I believed that a career in STEM was not out of my reach. Ultimately, I earned both my bachelor's and master's degrees in mathematics as a first-generation to college student. During my time tutoring mathematics as an undergraduate at the University of the Virgin Islands - the only Historically Black College or University (HBCU) not in the continental USA-I became acutely aware of the dominant narrative that asserted that mathematics was acultural (Gutiérrez et al., 2018). Another false narrative I encountered is that mathematics content can only be mastered by a select few (Martin, 2009) through the lack of interest, confidence, and affect for mathematics expressed by those I tutored. The pervasiveness of these narratives was also apparent in my subsequent teaching of mathematics at my high school alma mater. This prompted my commitment to confront those narratives as I created more humanizing spaces where my mathematics lessons leveraged and centred my learners' lived experiences, thus empowering them to see themselves as mathematicians. These experiences, along with my current role as a mother to two Black boys in US public schools, converge in my research where I investigate the nuanced ways that children's mathematics learning experiences are racialized within and across schools. In my work as a mathematics teacher educator, I promote humanizing, equitable, and justice-oriented teaching practices with elementary teacher candidates.

Our Research and Teaching Commitments Our collective experiences we shared above shape how we approach this work with our TCs and how we each engage in this line of research as part of our broader, equity-focused research agendas. As such, we are committed to strengths-based approaches and view the resources minoritized learners and their families and communities bring to any learning environment as assets rather than deficits. We also use an equity lens that moves beyond a focus on access (i.e. equal access to resources, high-quality instruction, and teachers) and achievement (i.e. focusing on remedying disparate student outcomes) to centre justice-oriented approaches (Madkins et al., 2020). (Re)designing (K. Gutierrez \& Jurow, 2016) mathematics and science education with a justice-oriented 
Table 1 Course goals for elementary mathematics and science methods
Elementary mathematics method (Morton)

This course is designed to help you transition from being a learner of mathematics to a teacher of mathematics. It is not designed to turn you into an expert mathematics teacher. Instead, it aims to help you think about some of the central questions in mathematics learning and teaching, who has ideas about these questions that they can defend articulately using applicable research, who knows about reform-based mathematics teaching and resources available to teachers, and who has the tools needed to become an advocate of and agent for equitable and justice-oriented mathematics education.

In this course, we will explore three themes: What mathematics? For whom? For what purpose? (Aguirre et al., 2013):

1. What mathematics?

- What mathematics concepts are children expected to learn in school and when? How can we teach these concepts in ways that are relevant to learners' lives?

- What mathematical understandings do children bring to the classroom and how can we leverage those in our mathematics instruction?

- What mathematics standards and resources can teachers draw from when developing and implementing mathematics lessons?

- What teaching practices can we use to promote equitable and rigorous mathematics teaching and learning?

2. For Whom?

- Who is a mathematician? What popular myths and stereotypes are associated with who is or isn't mathematically competent?

- How are our mathematics identities shaped by our mathematics learning experiences, and how does that consequently impact our teaching of mathematics?

- How do we centre the experiences, identities, and mathematical understandings of ALL children, especially those from traditionally marginalized groups in mathematics?

- How do we teach mathematics to children from diverse cultural, racial, social, and linguistic backgrounds?

- How do we partner with parents and communities in our mathematics teaching and learning?

3. For What Purposes?

- Why is mathematical literacy important? How can we explore the beauty and power of mathematics with our learners?

- What is the role of assessment and how can we learn to assess learners effectively?

- In what ways has mathematics been used to oppress groups of children and how can we promote humanizing mathematics instruction?

- How can we provide opportunities for our learners to engage with mathematics in ways that allow them to critically examine their world and confront social injustices?

Elementary science methods (Madkins)

This course is designed to develop your pedagogical repertoires related to teaching science to young children. Learners in this course will develop a critical understanding of science practices and have opportunities to experience and reflect upon evidence-based strategies for working with young learners in science learning environments. This course provides teacher candidates with strategies for teaching science to young children; thus, the focus is on varied science teaching strategies rather than science content knowledge development. Through collective dialogue, readings, and other assignments, learners will:

1. Extend their understandings of science as a process of sensemaking and learn to engage young children in science and engineering practices

2. Develop their abilities to recognize all children as capable sensemakers and use strategies for making science equity-focused and culturally relevant for all learners

3. Learn to pay attention to how learners think about scientific ideas (rather than which facts or vocabulary they know) and develop assessment strategies that inform their teaching

4. Develop strategies for eliciting learners' ideas and questions, engaging them in investigations, and supporting them in developing evidence-based explanations 5. Make progress towards meeting the Texas Science Generalist EC-6 Standards 
equity lens can support learners in developing critical consciousness, which is an individual's understanding of structural inequities and how to affect social change (Freire, 1970/2005), and their agentic selves while learning STEM concepts and practices.

Our preferences in how we refer to learners' identities and experiences are grounded in antideficit frames that push back against and decentre whiteness. For example, we use the term, learners, rather than students because children are always learning in and out of schools. It should be obvious that all children are learners. Yet, deficit narratives about minoritized children, especially Black children, suggest they do not want to learn or come from families and communities that do not care about them learning. Such narratives are commonplace within research, schools, and classrooms (Adair \& Sánchez-Suzuki Colegrove, 2021; Aguirre et al., 2013), and we see using the term, learners, as a way to push back against these narratives. We also use minoritized to refer to those communities who are of the global majority (Lim, 2020) but are often referred to as minorities or Students of Colour. In this manuscript, we focus on learners whose racialized identity is Black, knowing there are many ethnic identities associated with this group, especially within the USA. This includes individuals who identify as Black American, Black Canadian, Afro-Asian, AfroCanadian, Afro-Latinx, Afro-Indigenous, biracial, Caribbean, as well as individuals from over 50 African nations (e.g. Ghanaian, Somalian, Swazi). As researchers and teacher educators, we must remember that attending to learners' ethnic identities is important work because it supports our work in elaborating the nuances in learners' lived experiences (Lee, 2021). Relatedly, researchers, teacher educators, and teacher candidates must also recognize and use the racialized and ethnic identity terms the communities we work with prefer. For example, neither author would describe herself as African American, preferring Afro-Caribbean, Black, or Black American based on our lived experiences. This is imperative as we consider the anti-racist work of teacher education in urban and rural areas of Canada (e.g. Toronto, Vancouver, rural areas within Saskatchewan), urban enclaves in the USA with large Black immigrant populations (e.g. New York City, Boston, Miami), and our work with those whose ancestors were enslaved in the USA and across the Diaspora.

Finally, we acknowledge that there are many Black learners who are multilingual learners (see González-Howard \& Suarez, 2021) in Canadian and US-based classrooms, but do not adequately address their unique needs in this paper. These learners are most often classified as English language learners (ELLs) where their teachers typically provide English as a second language (ESL) support while some Canadian learners have instruction in French. Relatedly, while we seek to address the ways we can disrupt anti-Blackness in elementary STEM education, we do not give specific attention to another distinct form of racism, anti-indigeneity. Critical scholars have also called out the ways anti-indigenous racism operates in schools, classrooms, and science and mathematics education (Bang, 2020; Bang \& Marin, 2015; Brayboy, 2005; Jacob et al., 2018; Nxumalo, 2018; Tuck \& Yang, 2016). In particular, Western science erases indigenous ways of scientific knowing and doing and devalues more-than-human life (Bang, 2020; Nxumalo, 2018; Tallbear, 2011). Though addressing anti-indigenous racism within STEM education is incredibly important, here, we choose to focus solely on how we can disrupt anti-Blackness in elementary STEM education.

\section{Anti-Black Racism in Science and Mathematics Education}

Critical race theory (CRT) is a theoretical framework grounded in legal studies (Bell, 1995) that was introduced to examine race and racism and transform how race operates within systems. Within educational research, CRT has been used for over 25 years for scholarly inquiries that "examine the role of race and racism in education" (Dixson \& Rousseau Anderson, 2018, p. 121; Ladson-Billings \& Tate, 1995). Within STEM education specifically, some scholars have advocated for and used CRT as a lens 
to analyze the experiences of Black learners and advance solutions that can redress racial inequities (e.g. Bullock, 2017; Cochran et al., 2020; Joseph et al., 2017; Larkin et al., 2016; Mensah, 2019; Seriki, 2018). Collectively, this research helps us understand the endemic nature of race and racism in STEM education, the "pedagogical implications of race" (Larkin et al., 2016, p. 314), and how we might transform STEM teaching, learning, and teacher education.

Several scholars within educational research have extended foundational CRT scholarship to deeply examine the complexities of and address how race and racism operate for specific ethnoracial groups (e.g. TribalCrit, Brayboy, 2005), learners (e.g. DisCrit, Annamma et al., 2013), or educational contexts (e.g. DisCrit Classroom Ecology, Annamma \& Morrison, 2018). To this end, Dumas and ross (2016, p. 416) identified anti-Blackness to discuss and frame Black communities' "embodied lived experience of social suffering and resistance." ross, (2020) explains this further in a New York Times opinion piece:

Antiblackness is one way some Black scholars have articulated what it means to be marked as Black in an antiblack world. It's more than just "racism against Black people." That oversimplifies and defangs it. It's a theoretical framework that illuminates society's inability to recognize our humanity - the disdain, disregard, and disgust for our existence.

Within STEM education, some scholars have used anti-Blackness as a powerful lens for demonstrating how Black learners are marginalized and dehumanized within STEM learning environments and how "STEM education may perpetuate anti-blackness" (Cedillo, 2018, p. 253; Martin, 2019; Nxumalo, this issue; Williams et al., 2019; see Cedillo, 2018 for a full review). These scholars have highlighted many of the long-lasting effects of anti-Black racism in mathematics and science education, even in elementary education (Bliss, 2012, 2015; Gomez \& Conner, 2020; Martin, 2013; Sheth, 2019). For example, Martin (2019) analyses how stakeholders use language in reform documents to ostensibly support equity and inclusion efforts and shows how this rarely leads to humanizing mathematics learning experiences for Black learners. Brown (2019) demonstrates how Black learners' linguistic resources are devalued and scientific discourse patterns are dismissed within science classrooms. We also know young Black learners encounter exclusionary classrooms where their abilities and attitudes towards learning are questioned and socioemotional needs go unmet (Adair \& Sánchez-Suzuki Colegrove, 2021). This is especially true for Black girls, who are often pushed out of classrooms due to harsh disciplinary practices for minor offenses or even suspended or expelled from preschool classrooms (Epstein et al., 2017; Evans-Winters et al., 2019; Morris, 2015; Waite, 2021). Scholars blame racial hierarchies that position white and Asian learners at the top and Black, Indigenous, and Latinx learners at the bottom, which continue to fuel common narratives about who is or is not capable of engaging in mathematics and science learning (Martin, 2009; Sheth, 2019). Although documenting all of the ways anti-Blackness shows up in STEM education is beyond the scope of this article, we want to emphasize how these racist ideas and practices have a significant impact on young minoritized learners' mathematics and science learning experiences. Thus, it is imperative for TEs to work with TCs to examine, identify, and confront their potential deficit views of Black learners, if we are to disrupt anti-Black racism in elementary classrooms. We argue that in order to disrupt anti-Blackness in elementary STEM education, teachers need political clarity. As such, in the next sections we discuss political clarity and how it can be developed within elementary STEM methods courses.

\section{Political Clarity for Disrupting Anti-Blackness in Science and Mathematics Education}

Teaching is and always has been a political act, especially as it relates to protecting the socioemotional, academic, and physical needs of Black children and disrupting forms of anti-Blackness in schools and classrooms (Givens, 2021a, b; Grant et al., 2016; Madkins, 2011; McKinney de Royston et al., 2021; Smith, 2020). Though many researchers and practitioners view STEM fields, teaching and learning as 
apolitical and culture-free (see Cochran et al., 2020 for further discussion), critical scholars acknowledge and emphasize the political nature of teaching mathematics and science (Madkins \& McKinney de Royston, 2019; Gutstein, 2003; Secada, 1989; Vossoughi \& Vakil, 2018). It is important for TEs to support TCs in understanding the political nature of teaching, especially within elementary mathematics and science education, in order to develop political clarity. Political clarity (Bartolomé, 1994; Beauboeuf-LaFontant, 1999) is the understanding of the sociopolitical and classed realities that shape our learners' lived experiences, and how structural and school inequalities work to (re)produce differential learning experiences for minoritized learners. To develop political clarity and anti-racist teaching dispositions and practices, we have to support TCs in seeing how their beliefs are connected to their work in classrooms with young learners (Larkin et al., 2016; Madkins, 2016; Madkins \& Patterson, 2020). TCs must consider the ways minoritized learners have opportunities (or not) to (1) engage in disciplinary-specific practices, like investigating, sensemaking, or problem solving, (2) feel valued, and (3) "learn challenging ideas" in their classrooms (K. Gutiérrez \& Penuel, 2014; Windschitl \& Calabrese Barton, 2016, p. 1101). Additionally, TCs must grapple with understanding and addressing structural inequities within our society, STEM fields, and mathematics and science teaching and learning in order for learners to have more socially just and humanizing learning experiences (K. Gutiérrez \& Calabrese Barton, 2015; Mensah, 2019; Sheth, 2019; Warren, 2018). National and local science and mathematics standards (e.g. Common Core State Standards-Mathematics (CCSS-M), Next Generation Science Standards (NGSS), Ontario Curriculum, Texas Essential Knowledge and Skills) and frameworks on how to teach these subjects (e.g. NRC, 2012) do not often make this explicit connection for educators.

Thus, we must demonstrate the importance of developing TCs' political clarity in our science and mathematics methods courses. Though this development will occur both in and outside of universitybased teacher education spaces (e.g. lived experiences, other coursework, such as the multicultural courses or literacy methods courses), we have found ways to do so in our courses. This is just one part of the ongoing, daily work of developing anti-racist teaching dispositions (i.e. a teacher's beliefs, attitudes, and observable behaviors; see Warren, 2018) and instructional practices. This work is important for all TCs, no matter their racialized or ethnic identity. In the following section, we share specific examples of how TEs can do this work in the elementary methods course.

\section{Developing Elementary Teacher Candidates' Political Clarity: How Can We Work Within Elementary Science and Mathematics MethodsCourses?}

In this section, we elucidate how TEs can support TCs in developing political clarity to support their anti-racist teaching dispositions and practices. Teacher education researchers may also learn how they can design research projects to study this kind of work across contexts. We share examples from our university-based mathematics and science methods courses without being prescriptive. To be clear, we are Black women teacher educators and researchers at research-intensive institutions in the USA who work with undergraduate TCs, the majority of whom are white women. Our work in our elementary STEM methods courses has shifted over time based on our institutions, course length (semester vs. quarter), TC demographics (which we gather directly from our TCs since our universities do not provide us with access to our learners' demographic data), and other contextual factors. This is an important consideration for all teacher educators and researchers because contexts matter; contexts both shape and get shaped by our individual and collective work. Our lessons learned that we share here are reflective of this idea, and as such, we know that each teacher educator will have a unique way of engaging antiracist STEM teaching and learning across settings.

Because the elementary TCs we work with in any given semester are learning a range of instructional practices across content areas (e.g. literacy, social studies), they are often overwhelmed with 
information yet making connections across coursework. As they grapple with all of these new ideas, we aim to facilitate learning experiences that are indicative of the justice-oriented STEM teaching we want them to engage in their classrooms. Thus, TCs have examples of the kinds of lesson plans and instructional practices they can implement to disrupt anti-Blackness while engaging in sense-making processes about their coursework. Their subsequent pedagogical enactments will vary based on their dispositions, personalities, and individual contexts.

Relatedly, the TCs we work with are often in the beginning of their professional development coursework where they are learning how to support all learners using a range of instructional and management strategies (e.g. Universal Design for Learning Guidelines). Many of them are hyper-focused on classroom management strategies, such as participation structures or behavioral management, which is common at this point in their professional trajectories (Lortie, 1975). We also find that our TCs' definitions of equity are often synonymous with equality (e.g. fairness, equal access, providing all children with the resources they need) rather than those that promote social justice. As such, much of what they envision for equitable STEM instruction is through this equality lens and tends to focus on finding ways for learners to access content, such as modifying the informational text children might read for a lesson, or ensuring all children have access to technology to engage in a lesson. Though these are important aspects of teaching and learning, we also want our TCs to learn how to design elementary STEM classrooms that promote justice.

To this end, we are clear about how the instructional strategies we engage in our courses are related to specific design features. This means when we debrief demonstration lessons as a whole group (i.e. facilitate a whole group discussion with our TCs about the lesson we modeled), we ask them to share strategies or key moments that stood out to them. Next, we connect those key moments and strategies to three broad areas to show them how they might connect learners' lived experiences and social justice issues to math or science content to promote equity. Those three areas are (1) classroom design features, such as classroom management strategies specific to using science and mathematics materials or participation structures for young learners; (2) drawing and building upon learners' fluid and dynamic cultural practices and lived experiences without cultural appropriation, including ways to blur the lines between home and school or incorporating learners' repertoires of practice (see K. Gutiérrez \& Rogoff,

Table 2 Key features and constraints of course syllabi
Key features

- Centre readings and textbooks that uplift the relevant work of scholars from minoritized communities and/or critical scholars who use strengths-based perspectives in their research and practice. Be explicit with TCs about your choices for course readings included in your syllabus (i.e. you envisioned a course syllabus that draws upon evidence-based practices, prioritizing the scholarship of researchers from minoritized communities)

- When possible, rely upon textbooks and practitioner-focused journal articles written concisely and with accessible language about evidence-based practices or important theoretical frameworks.

- For course assignments, identify how you envision the assignment supporting TCs in meeting course goals and/or understanding what it means to be an anti-racist teacher. Invite TCs to provide their feedback and what they learned from the assignment.

Constraints

- TEs may be required to use a common syllabus, readings, and/or other course materials to ensure commonalities across multiple sections of a methods course. If you are required to include scholarship that is considered foundational—but has implicit or explicit deficit narratives-use the text(s) as an opportunity to demonstrate how these narratives can be implicit or explicit within the text, as well as the nuanced ways these narratives operate in schools and classrooms. 
2003); and (3) connecting content to social justice (e.g. inequities in access to and quality of healthcare, how science research has marginalized particular communities), identity development (e.g. supporting learners' STEM identities, seeing learners as scientists and mathematicians), and inequities in STEM education and fields (e.g. disparities in outcomes, gender inequities). Below, we offer just a few examples from our methods courses to make visible how we enact these practices within our STEM methods courses. For each example, we describe (1) course activity, which are available via email request with the corresponding author; (2) key features that support TCs' development in our course and/or over time; and (3) possible constraints within and across contexts (see Tables 2, 3, 4, and 5).

\section{Course Syllabi}

Though we teach different STEM courses (e.g. elementary mathematics methods, elementary science methods), we have commonalities across our course syllabi. For example, we both have course goals that encourage TCs to examine the why and for whom of teaching science and mathematics (see Table 1; Philip et al., 2018). We also both ask TCs to (re)consider the intellectual resources minoritized learners, especially Black learners, bring to mathematics and science classrooms. In so doing, we ask our TCs to uncover, identify, and confront deficit notions about learners' thinking and abilities. To facilitate these processes, we intentionally select course readings that can support TCs in understanding these ideas while they develop anti-racist teaching dispositions and practices. Below, we provide a detailed

Table 3 Key features and constraints of math (auto) biography assignment

\begin{tabular}{l} 
Key features \\
- The assignment requires TCs to reflect on their unique K-12 experiences in/out of \\
schools and those of someone they care deeply about, which can support empathy \\
development. Warren (2018) argues that within a teacher preparation program \\
that aims to decentre whiteness, TCs' empathy development can also foster their \\
development of cultural awareness, and subsequent cultural responsiveness towards \\
learners from diverse backgrounds. \\
- Storytelling is a powerful tool, especially within Black communities where oral and \\
written storytelling is a way of sharing our stories. Being explicit about using sto- \\
rytelling within the methods course signals to TCs how they need to provide space \\
for minoritized learners, families, and communities to share their stories-even in \\
math and science education. This is an important part of (re)humanizing learning \\
and classroom environments, as well as drawing upon experiential knowledge in \\
teaching. \\
- It provides an opportunity for TCs to (1) pay attention to the racial makeup of their \\
mathematics classes, (2) begin to notice patterns of disparate opportunities to learn \\
rigorous mathematics within and across classrooms (e.g. ability grouping within \\
classrooms where White children largely made up the "smart" group or remedial/ \\
regular math courses occupied mainly by minoritized learners), and (3) extrapolate \\
the possible explanations and resulting implications relative to structural racism. \\
- It requires TCs to make connections to how their experiences, feelings, and beliefs \\
might influence the kind of mathematics teacher they will be-or the kind of teacher \\
they want to be. This assignment allows space for growth and signals to TCs that \\
this is an ongoing process of (un)learning as part of their professional trajectories. \\
- Furthermore, this assignment supports TCs in conversations about the importance \\
of culturally responsive pedagogy, especially for learners who have been tradition- \\
ally marginalized in mathematics curricula. \\
Constraints \\
- It might be difficult to share. This requires the teacher educator to foster and main- \\
tain a safe classroom space for TCs to share deeply personal stories in the assign- \\
ment and aloud in class (if teacher educators choose to have them share). \\
\hline
\end{tabular}


Table 4 Key features and constraints of Diapers Lesson: Midnight Messages

\section{Key features}

- To foster sensemaking, this demonstration lesson is grounded in an anchoring phenomenon, which "is [something] observable" either in-person or by using media and comes from a designed or natural system (Lowell \& McNeill, 2019). This allows learners a challenge to grapple with for conceptual understanding that is standardsbased (e.g. NGSS; Ontario Curriculum, Texas Essential Knowledge and Skills).

- TCs engage authentically in science and mathematics practices (e.g. NGSS practices: investigating, constructing explanations, and/or analysing and interpreting data from evidence; CCSS mathematical practices: use tools appropriately or attend to precision).

- The lesson is contextualized in a way (but not the only way) that serves learners and their families (e.g. a diaper donation drive that the School of Social Work at the university was actually organizing). This can support TCs in thinking about the importance of making learning relevant to children and their communities. Be careful to choose contextualizing factors that do not reify anti-Black stereotypes or tropes.

- In addition to facilitating rigorous standards-based learning, the lesson lends itself easily to connecting a range of sociopolitical issues for multiple points of entry into conversations based on TCs' needs (e.g. sustainability, capitalism, diaper deserts).

- TCs are asked to make use of their lived experiences and share them with their classmates who may not have the same experience (i.e. those who have never changed a baby's diaper). It also invites TCs to use household items they use daily to measure liquids, allowing them to make connections to (and hopefully blur the lines between) school and home ways of scientific and mathematical ways of knowing and doing.

- It allows TEs and TCs to identify and examine their deficit framing of Black children and anti-Black tropes (e.g. culture of poverty, welfare mom, and other tropes).

- The anchoring phenomenon (e.g. figuring out how a disposable diaper absorbs liquid) offers an opportunity to explore (1) variations in cultural and classed practices (i.e. varied ideas about the how, what, and when) and (2) the need to decentre White middle class norms (e.g. how often we change a baby's diaper, brands and kinds of diapers, what counts as "wet," or decision-making about a baby's care).

Constraints

- Lesson occurs over two class sessions, which is considerable for a semester or quarter-long course. It is also expensive to facilitate and will require departmental or personal funds to purchase disposable diapers each time the course is taught.

- Requires the teacher educator and TCs to engage in difficult conversations which can inadvertently reify stereotypes if not handled well. Be sure to set or review established norms for a safe classroom space prior to the discussion.

explanation of Morton's textbook choice for her elementary mathematics methods course to represent our intentionality about such curricular choices.

The textbook The Impact of Identity in K-8 Mathematics: Rethinking Equity-Based Practices (Aguirre et al., 2013) has been a consistent and integral component of Morton's elementary math methods course since the 2017-2018 academic year. Aguirre et al. (2013) challenge teachers to reconceptualize their ideas about mathematics as a neutral and acultural content area and purport the notion that children have rich and intersecting identities that also include their identity as learners of mathematics. Within the chapters the authors consistently push back against common narratives that position learners from minoritized communities, particularly Black, Indigenous, and Latinx communities, as incapable of engaging in mathematics. Aguirre et al. (2013, p. 43) also address the important role that teachers have in disrupting racism in mathematics classrooms through teaching practices that include "going deep with mathematics, leveraging multiple mathematical competencies, affirming mathematics learners' identities, challenging spaces of marginality, and drawing on 
Table 5 Key features of collaborative lesson planning: social justice lesson
Key features

- There is a focus on mathematics standards (e.g. Common Core State Standards Texas, Essential Knowledge and Skills, Ontario Curriculum) and creating lessons that are meeting both the content and process standards for a given grade level.

- A performance-based activity for learners is included that is designed to be openended, allowing for multiple entry points, which is a key requirement for equitable mathematics teaching (Aguirre et al., 2013)

- There is careful consideration of social issues that are of interest to diverse learners in their classrooms, which aids in decentring whiteness.

- TCs can engage in this work collaboratively as they keep equity-based practices at the forefront in the creation of the lesson and explicitly discuss their intended use of those practices in the enactment of the lesson.

Constraints
- When engaged in creating lessons that have a social justice component, it is impor-
tant to begin this process with input from learners so that their experiences, under-
standings, and concerns are centred throughout the lesson. This ensures that the
topics selected are not imposed on learners and instead reflect those that they have
interest in learning more about and ultimately addressing. As such, in this assign-
ment, TCs must always be mindful of context as the topics selected can depend
heavily on issues present in local communities.

multiple resources of knowledge." As TCs read chapters of this book throughout the semester, they reflect upon and discuss what resonated with them and their fellow TCs. These discussions primarily occur online through a discussion board format via the course site (e.g. Canvas, Blackboard) as well as whole class discussions, allowing multiple opportunities for TCs to engage in transformative conversations that can potentially impact their own commitment to anti-racist mathematics teaching.

\section{Math (Auto)biography Assignment}

In this assignment adapted from Aguirre et al. (2013) and Bartell et al. (2019), TCs are asked to reflect on their mathematics learning experiences as children, their attitudes towards mathematics, and how that has evolved over time. As they reflect, they are asked to recount aspects of their mathematics learning experiences that may not have been apparent to them at the time, such as any differences in learners' identities (e.g. racialized, linguistic, gendered) within their mathematics classrooms. They are also asked to share if their lived experiences were incorporated into the mathematics curricula, as well as the kinds of mathematics learning experiences they had in their homes or communities. This might include keeping a running total of items during a supermarket shopping trip with a family member or measuring the ingredients for a birthday cake. Once they have engaged in this reflection, they are then asked to interview a significant person in their lives, such as a family member or romantic partner, to find out about their mathematics learning experiences and compare them with their own. After completing these reflections and interviews, the TCs are asked to discuss what type of mathematics teacher they aspire to be and how their experiences and those of their significant person inform that aspiration.

\section{Demonstration Lesson: Midnight Messages Diapers Lesson}

Madkins (re)designed this lesson over several years from an activity that is common in science and mathematics methods courses and in classrooms where learners try to figure out how a disposable diaper absorbs liquid (see Walker \& Wood, 2010, p. 17). The lesson occurs over two consecutive class sessions to allow TCs time to engage in the lesson itself and have considerable time for debriefing and 
sensemaking around the key components of the lesson. During the first class session, TCs discuss the assigned readings, which are selected to support their understanding of theoretical frameworks related to culturally relevant, rigorous, and standards-based science teaching (Bang et al., 2017; Boutte et al., 2010). They are also asked to bring in liquid measuring tools from home to use during the lesson (e.g. bottles, liquid containers, measuring cups and spoons) to model how everyday materials can be scientific tools at both home and school. Furthermore, the lesson is contextualized for the class by pretending that families within the "school community" will receive diaper donations from a local entity-and their class is responsible for deciding on the most absorbent diaper for purchase. In so doing, some learners are more motivated and invested in engaging in the lesson.

During the demonstration lesson, TCs are given a chance to observe newborn baby diapers and draw and write down in their science notebooks their experiences about changing diapers. They then share these with their tablemates and the whole group to create a collective understanding before investigating how and the extent to which the diaper absorbs liquid (modeled by water colored with food colouring). Next, in small groups of three or four, they devise an investigation plan and can use the materials they and the instructor brought from home, such as empty plastic water bottles or measuring spoons/cups, and/or those provided by the instructor (e.g. graduated cylinders, droppers). Once each team has a plan, they have at least 30 min to investigate; once they are done, they share their data on a class chart. Individual teams share out their processes and data with the whole group, and decide on the "best" diaper. Finally, TCs watch a video that supports them in thinking about diaper deserts (i.e. similar to food deserts, where communities have few places to purchase basic necessities) and the expense of diapering for all families. This supports them in uncovering deficit views, where learners and their families can purchase diapers in their school communities (i.e. inequitable access within diaper deserts), and the varied ways caregivers go about purchasing diapers. Finally, during the second class session, the discussion may continue before Madkins debriefs the lesson with her TCs and supports them in unpacking the lesson design features of the demonstration lesson aligned with the three broad areas (mentioned above).

\section{Developing a Social Justice-Focused Lesson}

In this assignment, adapted from Radical Math (http://www.radicalmath.org/), TCs engage in lesson planning processes to create a lesson that will be shared with other elementary TCs and inservice teachers with both science and mathematics learning goals and is connected to a social justice issue. TCs are instructed to select social justice issues that are likely to be relevant and important to the lives of the learners in the classrooms where they are placed for their initial clinical experiences (e.g. student teaching in classrooms two or more mornings per week). This assignment is intended to provide a space for TCs to practice centring the experiences and concerns of the learners they work with and facilitate the learning of rigorous STEM concepts to identify, confront, and address those issues.

In preparation for this assignment, TCs read chapter four of The Impact of Identity in K-8 Mathematics: Rethinking Equity-Based Practices entitled, "Cultivating Mathematical Agency: 'He Was Suspended for Being Mexican." This chapter recounts the initiation, development, and implementation of a lesson designed by a mathematics teacher in an urban middle school in response to a claim of racial profiling in the school made by the racially minoritized learners in his classroom. Through this example, TCs are able to see how a social issue of concern and relevance to the learners in a classroom can be investigated using rigorous mathematics. Furthermore, they begin to recognize how they can facilitate agency development among learners from marginalized populations to not just identify and explore social justice issues but also to encourage activism in response to those issues. TCs also access resources to aid in their lesson creation through the website Learning Mathematics Through a Social Justice Lens developed by The Learning Exchange and supported by Ontario's Ministry of Education. Through this website, TCs get access to resources to support their lesson development including classroom videos of learners engaged in a number of problem solving tasks designed to explore a social justice issue using mathematics. 


\section{Conclusion}

Anti-Blackness is prevalent within STEM education classrooms, especially in elementary mathematics and science classrooms. In this article, we have argued for disrupting anti-Black racism in elementary STEM classrooms in order to envision a future where young Black learners' full humanity is honoured. Though there are numerous ways to do so, we suggest one way to disrupt anti-Blackness in elementary STEM classrooms is to prepare teacher candidates to do this work and support them in developing the political clarity to do so. We have demonstrated how our intentional choices related to syllabi design, textbook selections, and assignment choices disrupt anti-Blackness in early schooling. These curricular choices are based on our prior educational, professional, and research experiences and are shaped by the unique university-based contexts in which we work. We have anecdotal evidence that these choices have supported the TCs we have worked with over time to develop more sophisticated understandings of deficit narratives, anti-Blackness, and either begin to or further develop their political clarity. One potential implication of our work is the importance of demonstrating with evidence how these efforts can support TCs in developing political clarity. We encourage teacher education researchers to investigate elementary STEM methods courses to examine how TCs can develop political clarity and the extent to which TCs show this clarity in their STEM lesson planning and implementation. Others might extend this work by following graduates of their teacher education programs into their future classrooms to determine the extent to which practicing elementary teachers develop anti-racist teaching dispositions and engage anti-racist teaching practices. What is most important is that we continue to address anti-Blackness within elementary STEM education and research and advance evidence-based strategies for redressing racial inequities.

\section{Declarations}

Conflict of Interest The authors declare no competing interests.

\section{References}

Adair, J. K., \& Sánchez-Suzuki Colegrove, K. (2021). Segregation by experience: Agency, racism, and learning in the early grades. The University of Chicago Press.

Aguirre, J. M., Mayfield-Ingram, K., \& Martin, D. B. (2013). The impact of identity in K-8 mathematics learning and teaching: Rethinking equity-based practices. The National Council of Teachers of Mathematics, Inc.

Annamma, S., Connor, D., \& Ferri, B. (2013). Dis/ability Critical Race Studies (DisCrit): Theorizing at the intersections of race and dis/ability. Race, Ethnicity and Education, 16(1), pp. 1-31. https://doi.org/10.1080/13613324.2012.730511

Annamma, S. A., \& Morrison, D. (2018). DisCrit classroom ecology: Using praxis to dismantle dysfunctional education ecologies. Teaching and Teacher Education, 73, 70-80. https://doi.org/10.1016/j.tate.2018.03.008

Bang, M. (2020). Learning on the move toward just, sustainable, and culturally thriving futures. Cognition and Instruction, 38, 434-444. https://doi.org/10.1080/07370008.2020.1777999

Bang, M., Brown, B., Calabrese Barton, A., Rosebery, A. S., \& Warren, B. (2017). Toward more equitable learning in science: Expanding relationships among students, teachers, and science practices. Helping students make sense of the world using Next Generation science and engineering practices, 33-58. National Science Teachers Association.

Bang, M., \& Marin, A. (2015). Nature-culture constructs in science learning: Human/non-human agency and intentionality. Journal of Research in Science Teaching, 52(4), 530-544.

Banks, J. A., Au, K. H., Ball, A. F., Bell, P., Gordon, E. W., Gutiérrez, K. D., Heath, S. B., Lee, C. D., Lee, Y., Mahiri, J., Nasir, N. S., Valdes, G., \& Zhou, M. (2007). Learning in and out of school in diverse environments: Lifelong, life-wide, life-deep. Center for Multicultural Education, University of Washington.

Bartell, T. G., Drake, C., Turner, E. E., \& Foote, M. Q. (2019). Transforming mathematics teacher education. Springer International Publishing.

Bartolome, L. (1994). Beyond the methods fetish: Toward a humanizing pedagogy. Harvardeducational review, 64(2), 173-195. https://www.jstor.org/stable/23478420 
Beauboeuf-Lafontant, T. (1999). A movement against and beyond boundaries: "Politically relevant teaching" among African American teachers. Teachers College Record, 100, 702-723.

Bell, D. A. (1995). Who's afraid of critical race theory. University of Illinois Law Review, 1995(4), 893-910.

Bennett, P. W. (2020, July 20). The educational experience has been substandard for students during COVID-19. Policy Options Politiques. https://policyoptions.irpp.org/magazines/july-2020/the-educational-experience-hasbeen-substandard-for-students-during-covid-19/

Bliss, C. (2012). Race decoded: The genomic fight for social justice. University Press.

Bliss, C. (2015). Science and struggle: Emerging forms of race and activism in the genomic era. The ANNALS of the American Academy of Political and Social Science, 661(1), 86-108.

Block, D. (2020, September/October). Why STEM needs to focus on social justice. Washington Monthly. https:// washingtonmonthly.com/magazine/september-october-2020/why-stem-needs-to-focus-on-social-justice/

Boutte, G., Kelly-Jackson, C., \& Johnson, G. L. (2010). Culturally relevant teaching in science classrooms: Addressing academic achievement, cultural competence, and critical consciousness. International Journal of Multicultural Education, 12(2).

Brayboy, B. M. J. (2005). Toward a tribal critical race theory in education. The Urban Review, 37(5), 425-446. https:// doi.org/10.1007/s11256-005-0018-y

Brown, B. A. (2019). Science in the city: Culturally relevant STEM education. Harvard Education Press.

Bullock, E. C. (2017). Only STEM can save us? Examining race, place, and STEM Education as property. Educational Studies, 53(6), 628-641. https://doi.org/10.1080/00131946.2017.1369082

Calabrese Barton, A., \& Tan, E. (2020). Beyond equity as inclusion: A framework of "Rightful Presence" for guiding justice-oriented studies in teaching and learning. Educational Researcher, 49, 433-440. https://doi.org/10.3102/0013189X20927363

Carter, P. L., \& Reardon, S. (2014). Inequality matters. William T. Grant Foundation. http://wtgrantfoundation.org/library/ uploads/2015/09/Inequality-Matters.pdf

Cedillo, S. (2018). Beyond inquiry: Towards the specificity of anti-Blackness studies in STEM education. Canadian Journal of Science, Mathematics, and Technology, 18, 242-256. https://doi.org/10.1007/s42330-018-0025-0

Centers for Disease Control (CDC). (2020, July 24). Health equity considerations and racial and ethnic minority groups. https://www.cdc.gov/coronavirus/2019-ncov/community/health-equity/race-ethnicity.html

Cochran, G. L., Boveda, M., \& Prescod-Weinstein, C. (2020). Intersectionality in STEM education research. In Handbook of Research on STEM Education (pp. 257-266). Routledge. https://doi.org/10.4324/9780429021381

Davis, L. P., \& Museus, S. D. (2019). What is deficit thinking? An analysis of conceptualizations of deficit thinking and implications for scholarly research. NCID Currents, 1(1).

del Carmen Salazar, M. (2013). A humanizing pedagogy: Reinventing the principles and practice of education as a journey toward liberation. Review of Research in Education, 37(1), 121-148.

Dixson, A., \& Dingus, J. (2008). In search of our mothers' gardens: Black women teachers and professional socialization. Teachers College Record, 110(4), 805-837.

Dixson, A. D., \& Rousseau Anderson, C. (2018). Where are we? Critical race theory in education 20 years later. Peabody Journal of Education, 93(1), 121-131.

Dumas, M. J., \& ross, k. m. (2016). "Be real black for me" imagining BlackCrit in education. Urban Education, 51(4), $415-442$.

Epstein, R., Blake, J., \& González, T. (2017). Girlhood interrupted: The erasure of Black girls’ childhood.

Evans-Winters, V. E., Ansari, Z., \& Sealey-Ruiz, Y. (2019). Response: "What does it mean to be young, Black, and female in America?" Education Week.

Freire, P. (1970/2005). Pedagogy of the oppressed (30th Anniversary ed.). Continuum.

Freire, J. A., \& Valdez, V. E. (2017). Dual language teachers' stated barriers to implementation of culturally relevant pedagogy. Bilingual Research Journal, 40(1), 55-69.

Givens, J. R. (2021a). Fugitive pedagogy:Carter G. Woodson and the art of Black teaching. Harvard University Press.

Givens, J. R. (2021b, May 21). What's missing from the discourse about anti-racist teaching. The Atlantic. https://www. theatlantic.com/ideas/archive/2021/05/whats-missing-from-the-discourse-about-anti-racist-teaching/618947/

Gomez, C. N., \& Conner, A. (2020). Impact of Cooney, Shealy, and Arvold's (1998) belief structures: A literature review and citation analysis. Journal for Research in Mathematics Education, 51(4), 468-503.

González-Howard, M., \& Suárez, E. (2021). Retiring the term English language learners: Moving toward linguistic justice through asset-oriented framing. Journal of Research in Science Teaching, 58(5), 749-752.

Grant, C. A., Brown, K. D., \& Brown, A. L. (2016). Black intellectual though in education: The missing traditions of Anna Julia Cooper, Carter G. Woodson, and Alain Leroy Locke. Routledge.

Guinier, L. (2004). From racial liberalism to racial literacy: Brown v. Board of Education and the interest-divergence dilemma. Journal of American History, 91(1), 92-118. https://doi.org/10.2307/3659616

Gutiérrez, R., Goffney, I., \& Boston, M. (2018). Rehumanizing mathematics for Black, Indigenous, and Latinx students. Annual perspectives in mathematics 2018: Rehumanizing mathematics for Black, Indigenous, and Latinx students. National Council of Teachers of Mathematics.

Gutiérrez, K. D., \& Jurow, A. S. (2016). Social design experiments: Toward equity by design. Journal of the Learning Sciences, 25(4), 565-598. https://doi.org/10.1080/10508406.2016.1204548 
Gutiérrez, K. D., \& Calabrese Barton, A. (2015). The possibilities and limits of the structure-agency dialectic in advancing science for all. Journal ofResearch in Science Teaching, 52(4), 574-583.

Gutiérrez, K. D., \& Rogoff, B. (2003). Cultural ways of learning: Individual traits or repertoires of practice. Educational Researcher, 32(5), 19-25. https://doi.org/10.3102/0013189X032005019

Gutiérrez, K. D., \& Penuel, W. R. (2014). Relevance to practice as a criterion for rigor. Educational researcher, 43(1), 19-23. https://doi.org/10.3102/0013189X13520289

Gutstein, E. (2003). Teaching and learning mathematics for social justice in an urban, Latino school. Journal for Research in Mathematics education, 34(1), 37-73. https://doi.org/10.2307/30034699

Hou, F., Frank, K., \& Schimmele, C. (2020, July 6). Economic impact of COVID-19 among visible minority groups. https:// www150.statcan.gc.ca/n1/pub/45-28-0001/2020001/article/00042-eng.html

Irizarry, Y. (2021). On track or derailed? Race, advanced math, and the transition to high school. Socius, 7, 1-21.

Jacob, M. M., Sabzalian, L., Jansen, J., Tobin, T. J., Vincent, C. G., \& LaChance, K. M. (2018). The gift of education: How Indigenous knowledges can transform the future of public education. International Journal of Multicultural Education, 20(1), 157-185.

Jafar, A. J. N. (2018). Emergency Medicine Journal, 35, 323-324. https://doi.org/10.1136/emermed-2017-207158

Joseph, N. M., Hailu, M., \& Boston, D. (2017). Black women's and girls' persistence in the P-20 mathematics pipeline: Two decades of children, youth, and adult education research. Review of Research in Education, 41(1), 203-227. https:// doi.org/10.3102/0091732X16689045

Katayama, D., McEvoy, J., Cruz Guevarra, E., \& Montecillo, A. (2020, May 13). How virtual learning exposed inequities in education. KQED. https://www.kqed.org/news/11817808/how-virtual-learning-exposed-inequities-in-education

Kendi, I. X. (2017). Stamped from the beginning: The definitive history of racist ideas in America. Bold Type Books.

Ladson-Billings, G., \& Tate, W. F. (1995). Toward a critical theory of education. Teachers College Record, 97, 47-68.

Larkin, D. B., Maloney, T., \& Perry-Ryder, G. M. (2016). Reasoning about race and pedagogy in two preservice science teachers: A critical race theory analysis. Cognition and Instruction, 34(4), 285-322.

Lee, C. D. (2021, 29 January). Addressing systemic racism through justice and equity: The role of faculty at a communityengaged, empowered university. University of Illinois at Urbana-Champaign, College of Education, Dean's Distinguished Lecture Series. https://www.youtube.com/watch?v=Wel1nwDnnbk

Leonardo, Z. (2009). Race, whiteness, and education. Routledge.

Lim, D. (2020, May 9). I'm embracing the term 'People of the Global Majority.' Medium.com. https://regenerative. medium.com/im-embracing-the-term-people-of-the-global-majority-abd1c1251241

Lortie, D. C. (1975). Schoolteacher: A sociological study. University of Chicago Press.

Lowell, B. R., \& McNeill, K. L. (2019). Keeping critical thinking afloat. Science Scope, 43(1), 64-69.

Madkins, T. C. (2016). Empowering teachers to change: A mixed methods examination of equity-oriented STEM instruction. (Doctoral dissertation, University of California, Berkeley).

Madkins, T. C. (2011). The Black teacher shortage: A literature review of historical and contemporary trends. The Journal of Negro Education, 80(3), 417-427.

Madkins, T. C., \& McKinney de Royston, M. R. (2019). Illuminating political clarity in science instruction. Science Education, 103, 1319-1346. https://doi.org/10.1002/sce.21542

Madkins, T. C., Howard, N. R., \& Freed, N. (2020). Engaging equity pedagogies in computer science learning environments. Journal of Computer Science Integration, 3(2), 1-27. https://doi.org/10.26716/jcsi.2020.03.2.1

Madkins, T. C., \& Patterson Williams, A. (2020, August 14). We choose to reimagine education: Centering love and humanizing pedagogies in a pandemic. Teaching and Learning During a Pandemic Blog Post Series. Albert Shanker Institute.

Martin, D. B. (2003). Hidden assumptions and unaddressed questions in Mathematics for All rhetoric. The Mathematics Educator, 13(2), 7-21. https://openjournals.libs.uga.edu/tme/article/view/1856

Martin, D. B. (2009). Researching race in mathematics education. Teachers College Record, 111(2), 295-338.

Martin, D. B. (2013). Race, racial projects, and mathematics education. Journal for Research in Mathematics Education, 44(1), 316-333.

Martin, D. B. (2019). Equity, inclusion, and antiblackness in mathematics education. Race Ethnicity and Education, 22(4), 459-478. https://doi.org/10.1080/13613324.2019.1592833

McKinney de Royston, M. R., Madkins, T. C., Givens, J. R., \& Nasir, N. S. (2021). “I'm a teacher, I'm gonna always protect you": Understanding Black teachers' protection of Black children. American Educational Research Journal, 58, 68-106. https://doi.org/10.3102/0002831220921119

Mensah, F. M. (2019). Finding voice and passion: Critical race theory methodology in science teacher education. American Educational Research Journal, 56(4), 1412-1456. https://doi.org/10.3102/0002831218818093

Mensah, F. M. (2013). Retrospective accounts in the formation of an agenda for diversity, equity, and social justice in science education. In J. A. Bianchini et al. (Eds.), Moving the equity agenda forward: Equity research, practice, and policy in science education, Cultural Studies of Science Education, 5 (pp. 317-335).

Milner, H. R. (2007). Race, culture, and researcher positionality: Working through dangers seen, unseen, and unforeseen. Educational Researcher 36;388-400 https://doi.org/10.3102/0013189X07309471 
Morales-Doyle, D., Vossoughi, S., Vakil, S., \& Bang, M. (2020, August 19). In an era of pandemic, STEM education can't pretend to be apolitical. Truthout Education and Youth Op-Ed. https://truthout.org/articles/in-an-era-of-pandemicand-protest-stem-education-cant-pretend-to-be-apolitical/?utm_campaign=Truthout+Share+Buttons

Morris, M. (2015). Pushout: The criminalization of Black girls in schools. New Press.

Morton, K., \& Riegle-Crumb, C. (2019). Who gets in? Examining inequality in 8th grade algebra. Journal of Research in Mathematics Education, 50(5), 529-554. https://doi.org/10.5951/jresematheduc.50.5.0529

Morton, K., \& Riegle-Crumb, C. (2020). Is school racial/ethnic composition associated with content coverage in algebra? Educational Researcher, 49(6), 441-447. https://doi.org/10.3102/0013189X20931123

National Assessment of Educational Progress (NAEP). (2015). NAEP Scores. https://www.nationsreportcard.gov/science 2015/

NAEP. (2016). The Nation's Report Card. 2015 Survey questionnaires results: Students' Views of Mathematics, Reading, and Science. https://www.nationsreportcard.gov/sq_students_views_2015/\#/

Nasir, N. I. S., \& Bang, M. (2012). Conceptualizing cultural and racialized process in learning. Human Development, 55(5/6), 247-249.

National Research Council (NRC). (2012). A framework for K-12 education: Practices, crosscutting concepts, and ideas. National Academies Press.

Nxumalo, F. (2018). Stories for living on a damaged planet: Environmental education in a preschool classroom. Journal of Early Childhood Research, 16(2), 148-159.

Nxumalo, F. (2019). Decolonizing place in early childhood education. Routledge.

Philip, T. M. (2011). An "ideology in pieces" approach to studying change in teachers' sensemaking about race, racism, and racial justice. Cognition and Instruction, 29, 297-329. https://doi.org/10.1080/07370008.2011.583369

Philip, T. M., Bang, M., \& Jackson, K. (2018). Articulating the "how," the "for what," the "for whom," and the "with whom" in concert: A call to broaden the benchmarks of our scholarship. Cognition \& Instruction, 36(2), 83-88. https://doi.org/10.1080/07370008.2018.1413530

Poujoulat, A. C. (2020, June 13). Protests across the globe after George Floyd's death. CNN.com. https://www.cnn.com/ 2020/06/06/world/gallery/intl-george-floyd-protests/index.html

Ross, k. m. (2020, June 4). Racism didn't kill George Floyd. Anti-Blackness did. The New York Times. https://www.nytimes. com/2020/06/04/opinion/george-floyd-anti-blackness.html

Secada, W. G. (1989). Agenda setting, enlightened self-interest, and equity in mathematics education. Peabody Journal of Education, 66(2), 22-56. https://doi.org/10.1080/01619568909538637

Seriki, V. D. (2018). Advancing alternate tools: Why science education needs CRP and CRT. Cultural Studies of Science Education, 13, 93-100. https://doi.org/10.1007/s11422-016-9775-Z

Sheth, M. J. (2019). Grappling with racism as foundational practice of science teaching. Science Education, 103(1), 37-60.

Sleeter, C. E. (2012). Confronting the marginalization of culturally responsive pedagogy. Urban Education, $20,1-23$. https://doi.org/10.1177/0042085911431472

Smith, C. (2020, December). Teaching should be political: How to talk about race in the classroom. The Atlantic. https:// www.theatlantic.com/magazine/archive/2020/12/bringing-politics-into-the-classroom/616934/

Souto-Manning, M., \& Winn, L. T. (2019). Toward shared commitments for teacher education: Transformative justice as an ethical imperative. Theory Into Practice, 58(4), 308-317.

TallBear, K. (2011). Why interspecies thinking needs Indigenous standpoints. Cultural Anthropology, 24, 1-8. http:// mathewarthur.com/whats-new/pdf/tallbear-interspecies-thinking.pdf

Tuck, E., \& Yang, K. W. (2016). What justice wants. Critical Ethnic Studies, 2(2), 1-15. https://doi.org/10.5749/jcritethnstud.2. 2.0001

Tuck, E., \& Yang, K. W. (2018). Toward what justice? Describing diverse dreams of justice in education. Taylor and Francis.

Vossoughi, S., \& Vakil, S. (2018). Toward what ends? A critical analysis of militarism, equity, and STEM education. In T. Buenavista \& A. Ali (Eds.), Education at war: The fight for students of color in America's public schools (pp. 117-140). Fordham University Press.

Waite, S. R. (2021). Black girls' voices matter: Empowering the voices of Black girls against co-opting and colonization (pp. 248-252). In O. Delano-Oriaran, M. W. Penick-Parks, S. Arki, A. Michael, O. Swindell, \& E. Moore, Jr., Teaching beautiful brilliant Black girls. Corwin.

Walker, P., \& Wood, E. (2010). The science teacher's activity a day. Jossey-Bass.

Warren, C. A. (2018). Empathy, teacher dispositions, and preparation for culturally responsive pedagogy. Journal of Teacher Education, 69(2), 169-183.

Williams, K. L., Burt, B. A., Clay, K. L., \& Bridges, B. K. (2019). Stories untold: Counter-narratives to anti-Blackness and deficit-oriented discourse concerning HBCUs. American Educational Research Journal, 56(2), 556-599. https:// doi.org/10.3102/0002831218802776

Windschitl,M., \& Calabrese Barton, A. (2016). Rigor and equity by design: Locating aset of score practices for the science education community. In D. H. Gitomer\& C. A. Bell (Eds.), AmericanEducation Research Association's Handbook of Research on Teaching $5^{\text {th }}$ edition, (pp. 1099-1158). Sage Publications. 
Young, E. (2010). Challenges to conceptualizing and actualizing culturally relevant pedagogy: How viable is the theory in classroom practice? Journal of Teacher Education, 61, 248-260. https://doi.org/10.1177/0022487109359775

Publisher's Note Springer Nature remains neutral with regard to jurisdictional claims in published maps and institutional affiliations. 